Marija Lakićević ${ }^{1}$

University of Kragujevac,

Faculty of Hotel Management and Tourism

\section{Zorica Sagić ${ }^{2}$}

High School of Vocational Studies, Užice
SCIENTIFIC REVIEW ARTICLE doi:10.5937/ekonomika1903077L

Received: August, 09. 2019. Accepted: September, 09. 2019.

\title{
ACCOMMODATION CAPACITIES AND THEIR UTILIZATION IN THE FUNCTION OF TOURISM DEVELOPMENT: CASE OF IVANJICA
}

\begin{abstract}
The development of the tourist offer of Ivanjica municipality can be shown, amongst other things, through the state of accommodation capacities and their utilization degree. The aim of this work is to show the accommodation capacities and their utilization in the municipality of Ivanjica and their influence on the development of the tourism of the area mentioned. Tourist activity is an important factor in increasing the economic activity of a country. The high-quality accommodation capacities provide this municipality the excellent conditions for the development of different selective forms of tourism. The results of the statistical analysis of the tourist traffic of Ivanjica municipality for the period $2011-2018$ are presented in this work. Secondary data obtained from Tourist organization of Ivanjica were used in the research. Based on the results of the analysis, conclusions on the current situation are drawn and recommendations for future activities and researches are made, with the aim of improving the sustainable tourist development of the municipality of Ivanjica.
\end{abstract}

Key words: tourism, destination, Ivanjica, accommodation capacities, rural tourism.

JEL classification: L83, Z30, Z32

\section{СМЕШТАЈНИ КАПАЦИТЕТИ И ЊИХОВА ИСКОРИШЋЕНОСТ У ФУНКЦИЈИ РАЗВОЈА ТУРИЗМА ИВАНИЦЕ}

\begin{abstract}
Апстракт
Развијеност туристичке понуде опитине Ивањица може се приказати, између осталог, кроз стање смештајних капаџитета и степена њихове искоришћености. Циь рада је приказ смештајних капаџитета и юхове искоришћености у општини Иваница и юихов утииај на развој туризма поменуте области. Туристичка делатност је битан чинилац повећања економских активности једне земье. Висококвалитетни смештајни капаџитети овој општини омогућавају изванредне услове
\end{abstract}

\footnotetext{
${ }^{1}$ marija.lakicevic@kg.ac.rs

${ }^{2}$ zoricasagic@gmail.com
} 
за развој различитих селективних облика туризма. У раду су приказани резултати статистичке анализе туристичког промета опитине Ивањища за период 2011 2018 године. У истраживағу су коришћени секундарни подаџии добијени од ТО Иваница. На основу резултата анализе, изводе се закључци у вези тренутне ситуације и дају се препоруке за будуће активности и истраживања, а све у цииьу побољшаға одрживог туристичког развоја општине Ивањица.

Кључне речи: туризам, дестинација, Ивањица, смештајни капацитети, рурални туризам.

\section{Introduction}

Tourism is one of the most complex, most dynamic economic and socio spatial phenomena of the modern world, which has become a global phenomenon in a relatively short period of time (Šušić, 2019, p.27). Knowing that the tourism sector is able to generate significant social, economic and cultural benefits and development, looking for novel ways to improve this sector is more than justified (Gavrilović, 2018, p.36). Tourism is one of the largest and fastest growing industries in the world (Edgell, 1990, p.3). In both developed and developing countries, tourism is often supposed to be a viable means of raising the economic activity of the regions (Hall, 1999, p.274). So today, tourism is one of the most important and fastest growing industries, characterized by the need for continuous diversification of products. Today, tourism has grown from one small activity to an activity that is crucial for the economic growth and development of a country (Lakićević, 2018, p.99). The latest trends in this industry suggest an increased demand for new alternative forms of tourism, where rural tourism takes a significant place.

The fact that rural tourism enterprises tend to be small scale and supply a highly seasonal market present several other challenges for rural development. Not all rural areasare equally attractive for rural tourists and simply providing accommodation facilities does not guarantee demand. The total product package must be enough to attract and keep tourists,offering suitable opportunities for spending (Gannon, 1994). The quality of products and services must match tourist's demands and expectations (Long \& Lane, 2000).

Rural tourism is a result of the development of cities and industry. Modern trends in tourism, in the era of increasing urbanization, environmental pollution, detachment from nature have led to an increasing orientation of tourism flows towards rural areas, rural destinations. Thus, tourism has become a significant factor in the revitalization of villages in Ivanjica municipality because it ensures the economic and social security of rural households through: establishing migrations to the town and returning to the village of those who have left before, increasing production and enabling the agricultural products placement, domestic crafts and products of old crafts through boarding and nonboarding consumption, preservation of traditional architecture, customs and folklore. Nevertheless, the rural areas of Ivanjica region are areas of exceptional value and represent the true ecological oases. The natural features and tourist potential of Ivanjica are numerous and various. They are distinguished by traditional culture and diversity of ethno-cultural heritage (Marković, 2008).

The municipality of Ivanjica is in the southwestern part of central Serbia. The region of Ivanjica, in relation to the territory of central Serbia, as well as the entire territory 
of the country, has a marked peripheral position. The tourist position is somewhat less favorable than some competitive destinations due to spatial dislocation from the main tourist routes. This was not an obstacle for tourists looking for a vacation in an authentic town, surrounded by a mountainous area with environment minimally altered.

Until half a century ago, Ivanjica was a typical rural area, isolated in terms of traffic and it was insufficiently developed. The increasing tourism and traffic in the last few decades have led to the development of tourism as well. Indeed, the beginnings of the rural tourism of the former Yugoslavia are related to the villages of the Moravian region. Today, the municipality of Ivanjica has significant anthropogenic tourist values (archaeological, monumental, ethnographic, ambient and manifestation). Along with natural potentials, they make an enormous tourist potential (Ostojić, 2008). Ivanjica was declared an aerial spa in the area of $2.156,50$ ha by the Decree of the Government of the Republic of Serbia.

When speaking of the region of Ivanjica, we need to consider several interesting data that point to the movements and possibilities of further development, of Ivanjicaabove all, as the most developed and most perspective center, with its hinterland Golija. Also, it should be noted that the Biosphere Reserve "Golija-Studenica" is the first and only reserve in Serbia that is included in the UNESCO program.

All forms of tourism, such as health, rural, sports and recreational, youth, excursion, manifestation, hunting and fishing, are possible in this area. Each summer, Ivanjica organizes a cultural event "Nusicijada", that was included in the best European festivals by the European Commission "Europe for Festivals, Festivals for Europe" (EFFE). So, tourism in the region of Ivanjica is an obvious reality and the future direction of the economic development of the municipality. Viewed in terms of population, our country has the largest number of events in the world (Lakićević, 2016, p.441). By the implementation of specific activities, cultural resources could be transformed into attractive tourist products and then successfully positioned on the national and international cultural tourism market. Development of cultural tourism creates a good base for increasing the general welfare of the inhabitants and the entire region to which it belong (Žarevac, et.al., 2013, p.195).

\section{Accommodation capacities and their utilization}

Accommodation facilities are basic elements of the material-technical base of tourism since they facilitate the visitors' stay in a destination and constitute a basis for the further development of the destination. This is the reason why they are considered to be a core source for the sustainable competitiveness of a destination and their lack "acts as a constraint on overnight visitor numbers" (Ritchie \& Crouch, 2003, p. 246).

It is very important to determine how tourism in Ivanjica develops based on supply and demand and utilization of existing capacities. Table 1 shows the tourist traffic in Ivanjica from 2011 to 2018. 
Table 1: Tourist traffic of Ivanjica municipality for the period 2011-2018.

\begin{tabular}{|c|c|c|c|c|c|c|c|c|}
\hline Year & & $\mathbf{N}$ & Mean & Median & Mode & $\begin{array}{l}\mathrm{St} \text { a } \mathrm{nd} \text { a } \mathrm{rd} \\
\text { Deviation }\end{array}$ & Min & Max \\
\hline \multirow{9}{*}{ 릉 } & Number of rooms & 8 & 53 & 48,5 & 26 & 31,924 & 18 & 108 \\
\hline & Number of apartments & 5 & 5,2 & 5 & 2 & 3,421 & 2 & 10 \\
\hline & Number of beds & 8 & 133,75 & 117 & 94 & 74,308 & 42 & 270 \\
\hline & Number of domestic tourists & 6 & 2526,33 & 1776 & 249 & 2579,928 & 249 & 6940 \\
\hline & Number of foreign tourists & 5 & 279,8 & 88 & 30 & 361,334 & 30 & 880 \\
\hline & Number of overnight stays of domestic tourists & 6 & 15625,3 & 5942 & 1007 & 25296,012 & 1007 & 66350 \\
\hline & Number of overnight stays of foreing tourists & 5 & 728,6 & 176 & 65 & 1036,201 & 65 & 2524 \\
\hline & Total number of tourists & 6 & 2759,5 & 1976,5 & 279 & 2690,962 & 279 & 7028 \\
\hline & Total number of overnight stays & 6 & 16232,5 & 7564 & 1072 & 25177,437 & 1072 & 66526 \\
\hline \multirow[b]{9}{*}{$\frac{1}{3}$} & Number of rooms & 8 & 48,38 & 33 & 6 & 38,037 & 6 & 108 \\
\hline & Number of apartments & 4 & 5 & 2,5 & 2 & 5,354 & 2 & 13 \\
\hline & Number of beds & 8 & 131,88 & 107 & 94 & 79,319 & 42 & 270 \\
\hline & Number of domestic tourists & 6 & 2505,17 & 2121 & 240 & 2289,532 & 240 & 6085 \\
\hline & Number of foreign tourists & 5 & 195,6 & 103 & 20 & 261,459 & 20 & 659 \\
\hline & Number of overnight stays of domestic tourists & 6 & 15457,5 & 4327 & 750 & 22413,932 & 750 & 57680 \\
\hline & Number of overnight stays of foreign tourists & 5 & 399,8 & 149 & 30 & 557,711 & 30 & 1376 \\
\hline & Total number of tourists & 6 & 2668,17 & 2505 & 260 & 2359,056 & 260 & 6188 \\
\hline & Total number of overnight stays & 6 & 15790,7 & 5015 & 780 & 22348,43 & 780 & 57783 \\
\hline \multirow[b]{9}{*}{$\frac{m}{\vec{N}}$} & Number of rooms & 8 & 37,75 & 27,5 & 18 & 33,005 & 6 & 108 \\
\hline & Number of apartments & 5 & 18 & 3 & 2 & 29,436 & 2 & 70 \\
\hline & Number of beds & 8 & 132 & 110 & 50 & 84,801 & 50 & 270 \\
\hline & Number of domestic tourists & 6 & 2534,5 & 2080,5 & 156 & 2714,937 & 156 & 7145 \\
\hline & Number of foreign tourists & 5 & 184,4 & 65 & 11 & 324,021 & 11 & 762 \\
\hline & Number of overnight stays of domestic tourists & 6 & 15025,8 & 4311 & 277 & 23423,906 & 277 & 60660 \\
\hline & Number of overnight stays of foreing tourists & 5 & 488,6 & 203 & 11 & 764,024 & 11 & 1842 \\
\hline & Total number of tourists & 6 & 2688,17 & 2198,5 & 167 & 2778,212 & 167 & 7160 \\
\hline & Total number of overnight stays & 6 & 15433 & 5333,5 & 288 & 23329,527 & 288 & 60755 \\
\hline
\end{tabular}




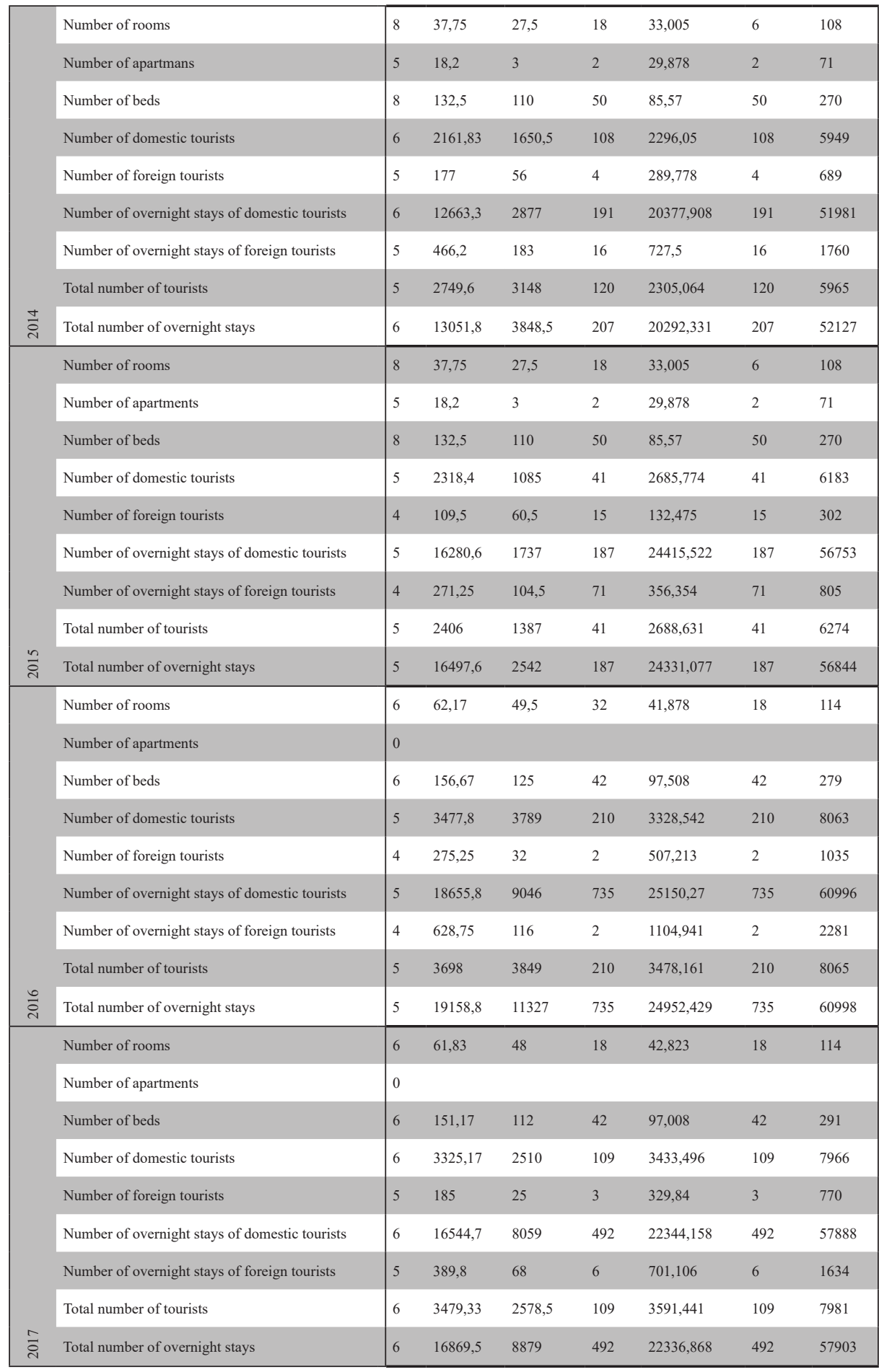




\begin{tabular}{|c|c|c|c|c|c|c|c|c|}
\hline & Number of rooms & 6 & 61,17 & 48 & 18 & 42,654 & 18 & 114 \\
\hline & Number of apartments & 0 & & & & & & \\
\hline & Number of beds & 6 & 149,67 & 125 & 42 & 91,577 & 42 & 268 \\
\hline & Number of domestic tourists & 5 & 3452,8 & 4268 & 177 & 3111,89 & 177 & 7129 \\
\hline & Number of foreign tourists & 3 & 338,67 & 49 & 2 & 542,929 & 2 & 965 \\
\hline & Number of overnight stays of domestic tourists & 5 & 19052,4 & 10781 & 1048 & 24046,546 & 1048 & 58970 \\
\hline & Number of overnight stays of foreign tourists & 3 & 792,33 & 736 & 4 & 817,956 & 4 & 1637 \\
\hline & Total number of tourists & 5 & 3656 & 4317 & 179 & 3289,882 & 179 & 7129 \\
\hline$\stackrel{\sim}{\circ}$ & Total number of overnight stays & 5 & 19527,8 & 12418 & 1052 & 23946,246 & 1052 & 58970 \\
\hline \multirow{9}{*}{$\stackrel{\Xi}{\leftrightarrows}$} & Number of rooms & 58 & 48,76 & 32 & 18 & 35,849 & 6 & 114 \\
\hline & Number of apartments & 24 & 13,25 & 3 & 2 & 22,549 & 2 & 71 \\
\hline & Number of beds & 58 & 138,72 & 112 & 100 & 81,348 & 42 & 291 \\
\hline & Number of domestic tourists & 45 & 2768,07 & 2333 & 41 & 2631,054 & 41 & 8063 \\
\hline & Number of foreign tourists & 36 & 212,89 & 62,5 & 15 & 318,243 & 2 & 1035 \\
\hline & Number of overnight stays of domestic tourists & 45 & 16041 & 4447 & 187 & 21539,591 & 187 & 66350 \\
\hline & Number of overnight stays of foreign tourists & 36 & 509,5 & 167 & 226 & 722,026 & 2 & 2524 \\
\hline & Total number of tourists & 44 & 3002,7 & 2761,5 & 41 & 2722,018 & 41 & 8065 \\
\hline & Total number of overnight stays & 45 & 16448,6 & 6207 & 187 & 21456,816 & 187 & 66526 \\
\hline
\end{tabular}

\section{Source: Authors}

Analyzing the tourist traffic in Ivanjica for the period 2011-2018, it was found that the number of overnight stays, domestic and foreign tourists was constantly declining. Only after 2015 there was an increase in number of overnight stays of both domestic and foreign tourists. Analyzing all other tourist offerparameters, it was found that since 2015 there has been a capacity decrease, i.e. the number of available beds has been reduced.

Some more important accommodation capacities in this area should also be mentioned, and those are: (http://ivanjica.gov.rs/turizam/):

- Hotel Park - the accommodation facility is ranked with four stars. It has 140 beds in single and double rooms and four suites, a restaurant, festive hall, congress hall, small wellness center; an indoor swimming pool, sauna, Jacuzzi, massage parlor, steam bath and gym, hotel bar, large terrace that enters the city park and a promenade along the river Moravica with waterfall, the visual symbol of the town.

- City hotel - it has 42 beds in single, double and triple rooms with their own bathrooms, TVs and telephones in rooms. The integral parts of the hotel are the restaurant and supermarket. The hotel also has 3 exclusive suites within the restaurant "Dubrava".

- Institute for Specialized Rehabilitation - it has 270 beds in single, double and triple rooms, internist-hematological laboratory and a physical medicine and rehabilitation block, an indoor swimming pool, restaurant, park and small sports ground. 
- Golija Resort - it used to be war and military invalidsresort. It has 152 beds in single and double rooms, a restaurant with 300 seats and a summer garden with 800 seats.

- Hotel Javor - the accommodation facility ranked with two stars, owned by the company "Mona". It has 92 beds in double and triple rooms, entertainment hall and parking space for their guests.

- Mountain Hut Golijska Reka - it is owned by the company "Srbijašume" Golija. It has 92 beds, of which 14 are in the hut itself, in double rooms and 80 in triple rooms and several rooms with more beds in two depandans next to the hut. Next to the mountain hut there is a football field, small sports grounds and a cable car leading to Janko's stone.

- Hotel Logos - the accommodation ranked with three stars, it has 67 beds in double and triple rooms and suites with hydromassage cabins in bathrooms, a restaurant with 60 seats, large hall with 180 seats, mini SPA center with two saunas, Jacuzzi, massage room, table tennis, disco and playroom. It has a parking lot for their guests, and there are sports fields in the immediate vicinity.

- Ivanjički konaci - it is equipped with the latest equipment and furniture. There are twelve luxury suites and a separate house as a whole, which has a spacious living room with fireplace, comfortable bathroom, kitchen, two bedrooms and a large covered terrace with a beautiful view of the mountain ranges of Javor and Golija.

Table 2. Utilization of accommodation capacities

\begin{tabular}{lllllll}
\hline Year & N & Mean & Median & $\begin{array}{l}\text { Standa } \mathbf{r} \text { d } \\
\text { Deviation }\end{array}$ & Min & Max \\
\hline 2011 & 6 & 26,1757 & 21,695 & 23,86227 & 1,56 & 67,5 \\
\hline 2012 & 6 & 27,9733 & 13,782 & 29,03212 & 0,93 & 70,61 \\
\hline 2013 & 6 & 24,6169 & 13,2557 & 26,06072 & 0,32 & 61,65 \\
2014 & 6 & 20,5208 & 9,7507 & 24,04831 & 0,23 & 52,89 \\
\hline 2015 & 5 & 24,9223 & 4,6429 & 31,33001 & 0,76 & 60,68 \\
\hline 2016 & 5 & 29,1696 & 20,6886 & 30,20736 & 0,92 & 61,9 \\
\hline 2017 & 6 & 28,9039 & 21,9677 & 29,90339 & 1,32 & 63,46 \\
\hline 2018 & 5 & 33,1356 & 22,6813 & 34,25438 & 1,45 & 74,04 \\
\hline
\end{tabular}

Source: Authors

On average, the best utilization of accommodation capacities was in 2018 with $33.14 \%$ (std. deviation $=34.25$ ), while the lowest utilization was in 2014 with $20.52 \%$ (std. deviation $=24.05)$. Also, we note that in the observed period, more than half of individual facilities have below-average occupancy rate $(\mathrm{M}>\mathrm{Me})$.

By analyzing individual facilities, it is noted that the lowest occupancy rate has a private accommodation. The term private accommodation originates from private ownership. Ingram (1996, p.30) interprets the importance of private accommodation 
and the quality of service being offered by taking into consideration the opinions and standpoints of owners of private accommodation facilities in order to obtain highest quality standardisation of private accommodation capacities.

\section{Chart 1. Average utilization of capacities in the observed period}

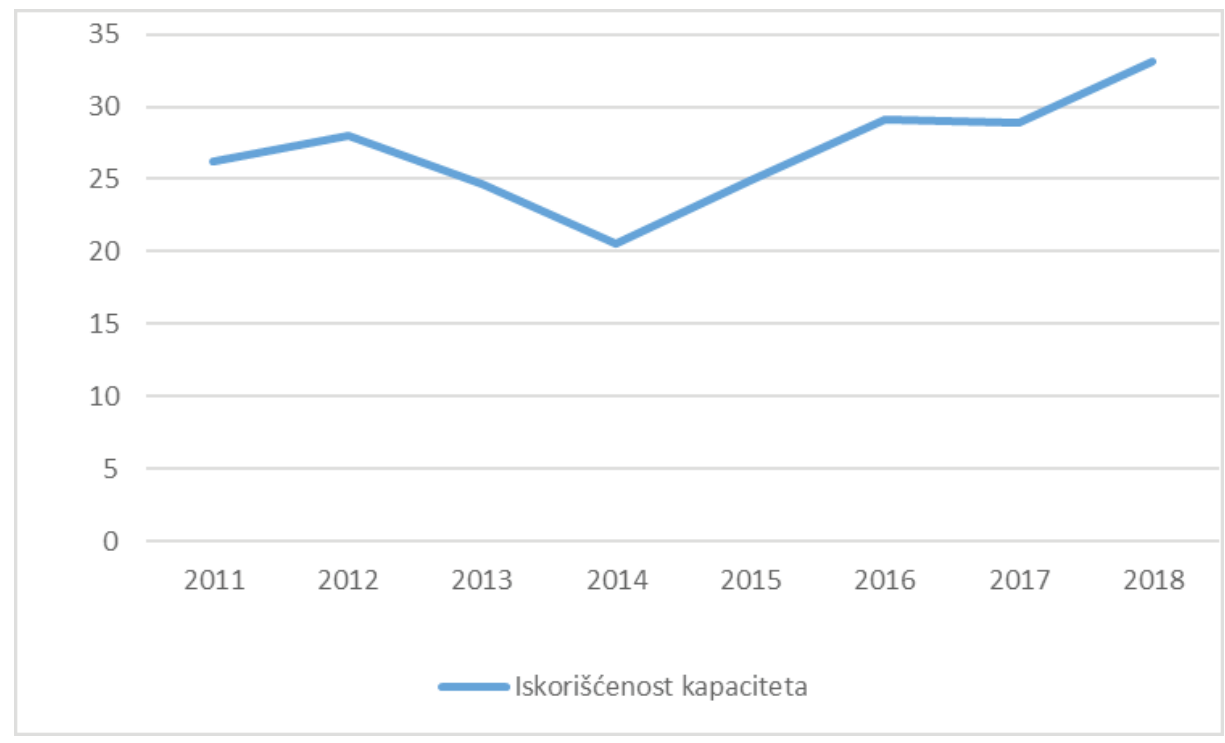

Source: Authors

On the chart, it can be noted that since 2016 there has been a better utilization of accommodation capacities, and the lowest utilization of accommodation capacities was in 2014 .

All these parameters are a good indicator for the further development of tourism in Ivanjica. We should not forget the great activity in attracting new guests by various tourist events, good marketing and various other specific forms of tourism. However, it is obvious that it is necessary to animate a large number of rural households in order to get involved in the tourist offer of rural tourism, and especially to intrigue young people in the villages to give new life to their homes, adapt and revive them with new facilities in order to be attractive to many tourists from urban areas who are looking for peace, tranquility and fresh air which is rich in Ivanjica.

Rural tourism has long been considered a means of achieving economic and social development and regeneration. More specifically, it has been widely promoted as an effective source of income and employment, especially in peripheral rural areas (Sharpley, 2002). Serbia has respectable resources for the development of rural tourism (natural and social). However, practically there is a problem because local stakeholders are not able to recognize the possibility of putting these resources in an appropriate manner in the function of tourism development, as well as the local communities, more broadly (Vukovic, P., 2018, p.81). 


\section{The importance of the mountain Golija for the development of tourism}

Golija Nature Park extends to the territory of five local municipalities - Ivanjica, Sjenica, Raska, Kraljevo and Novi Pazar. In July 2001, the Government of the Republic of Serbia issued the Decree to place Golija mountain under the protection of the "Golija Nature Park" and classify it as the First Category of protection as a natural resource of exceptional importance (it was declared the First Category Park in 2000). Then UNESCO categorized it as the Biosphere Reserve (2001), which was the only biosphere reserve in Serbia until recently. In fact, traffic isolation, economic underdevelopment, extreme depopulation and low social standard of the population are key factors influencing the preservation of the natural environment (Miljanović, 2005).

It is an area of 73,000 hectares and it has a plan for detailed regulation of all municipalities together and it develops about 700 kilometers of corridors (traffic and communal). In this regard, the Spatial Plan of the special purpose of Nature Park Golija is a long-term planning document that is adopted for the period up to 2021. In the Official Gazette of the municipality of Ivanjica, the decision was made on the plan adoption for detailed regulation of the ski center Golija on the territory of the municipality of Ivanjica. This plan regulates the area, within the zone of the planned ski resort and part of the tourist unit on mountain Golija (Official Gazette of Ivanjica Municipality, 2017, p.5)

Most of them are in the territory of Ivanjica, since $50 \%$ of Golija Nature Park belongs to this municipality. Golija is undoubtedly one of the most beautiful and the richest mountains in terms of forests in Serbia. It is the highest mountain in southwestern Serbia. As mentioned above, based on the natural characteristics, Golija is a part of the International Coordinating Council Act by UNESCO program. This area often carries the epithet of an aerial spa because climatic conditions favorably affect human health (Milovanović, et.al, 2010).

Golia has a good basis for ski trails construction and for mild walks recreation and hiking in the almost untouched nature. Tourism at Golia is developing at a high speed; In the last 10 years Golija has got modern and well-organized ski trails, cable cars and accompanying ski facilities. During the winter, there are guests from all over Serbia and abroad. Tourists visit Golija even during the summer.

There is a hotel "Golija" on Odvracenica, and on the side of Ivanjica, there is also "GolijskaReka".

Hotel "Golija", on the mountain with the same name, has 100 beds in single, double, triple and quadruple rooms and suites. Each unit has a separate bathroom, TV, and most of them have a balcony overlooking the mountain. Besides the hotel accommodation, there are also numerous villas (http://www.turistickiklub.com/objekat/golija). Also, on Golija Mountain at a height of $1408 \mathrm{~m}$ there is a Sport and Recreation Resort "GolijskaReka".It has 106 beds in the hotel and two depandances. Within the resort, there is a football field and sports and tennis playgrounds as well. A special attraction is walking to the Janko's stone (1833 $\mathrm{m}$ a.s.1.), as well as a marked long, health trail.

The facility is suitable for children's stay (School in nature).

The basic goal of the Plan is to create the conditions for arranging and construction of the planned ski center with ski, recreational and tourist facilities, equipped with the corresponding ski, traffic and communal infrastructure. The immediate goals of constructing and arranging Golija ski center are as follows: 
- $\quad$ establishment, development and construction of the planned ski center Golija with the appropriate tourist-recreational structure;

- formation of complexes with accommodation and central public facilities, cultural, entertaining, catering, recreational sports facilities in both indoor and outdoor areas, as well as the content of tourist services in function of ski resorts;

- formation of the starting and ending hubs of the ski resort with entrances and terminals, construction of ski infrastructure (cable cars, ski lifts, conveyor belts, ski trails, ski schools grounds) and accompanying technical facilities in function of the ski resort;

- maintenance of access roads, planning and construction of parking lots and garages, superstructure facilities and technical infrastructure;

- regulating and shaping spontaneously formed subcategories;

- embodiment of the future identity of the tourist zone based on the existing characteristics of the landscape and traditional forms of construction;

- providing a large number of daily excursions, primarily for winter and summer offers;

- establishment of high standards for Golija Nature Park environment protection in the field of water protection, district heating substation, automobile traffic, communal hygiene and noise protection through planned instruments and measures for each individual area;

- $\quad$ providing conditions for the phase construction of the planned ski center.

Full utilization of capacities, intensification of investments in tourism infrastructure and education of appropriate professional staff are also of special importance. Inclusion in the contemporary trends of the international market, supply adaptation to the modern conditions and raising the quality of the supply to a higher level would lead to a greater development of this branch of economy (Marković et.al, 2011, p.81).

\section{Conclusion}

Tourism, as a very important industry activity, has got many manifestations. One of the most important forms of tourism, especially in countries like Serbia, is rural tourism. The municipality of Ivanjica is an example of a tourist region where rural and health tourism is developing, as dictated by the geographical and social characteristics of this area. In order to fulfill its function and help the development of Ivanjica industry, tourism in this area must adapt its products to the needs and desires of existing and potential guests.

It is interesting to point out that Ivanjica and the surrounding areas were pioneers of rural tourism even in the time of SFR Yugoslavia. Although this area has a relatively unfavorable geographical position, compared to other more attractive destinations, future investors in tourism of the municipality of Ivanjica should not consider this as an obstacle to their investment. On the contrary, the relative geographical isolation of this region can be used as a comparative advantage in the development of tourism. Ivanjica, as a tourist destination, has very little (if at all) changed its environment and its peculiarities in the process of tourism development in the past. Therefore, this area is suitable for the 
development of health tourism, whose development requires the existence of clean air, water and land. Emphasis should be placed not only on the development of tourism, but on the development of sustainable tourism as well. It is important to find the appropriate balance between the tourism development enforcement in order to increase the economic activities of the area on one hand and preserving the clean environment on the other.

The tourism development of this region is a reality and obvious future direction of the economic development of the municipality of Ivanjica. During the observed analyzed period, a decrease in accommodation capacities was noticed a few years ago. There was also an increase in overnight stays. The problem is more in poor accommodation capacity, than in its insufficiency, especially in private accommodation. Looking at the current situation and anticipating the future situation inthe tourism of Ivanjica, one can notice that the problem lies not in the lack of potential, nor in the lack of a vision of future development, but in recognizing these potentials by the authorities.

If we look at the present situation and anticipate the future situation in the tourism of Ivanjica, it can be seen that the problem lies not in the lack of potentials, nor in the lack of a vision of future development, but in unrecognition of these potentials by the authorities in practice.

Further challenges to the management of tourism development in the municipality of Ivanjica are the maintenance of the existing infrastructure and construction of a new one, the establishment and respect of high standards of environmental protection, more intensive investment in the existing infrastructure and the construction of a new one along with the accommodation facilities, better utilization of existing capacities, shaping of the tourist destination identity and professional staff education.

\section{References}

Edgell, D. L. (1990). International tourism policy. Van Nostrand Reinhold, New York. Gannon A. (1994). Rural tourism as a factor in rural community economic development for economies in transition, Journal of Sustainable Tourism, 2(1-2), 51-60, DOI: 10.1080/09669589409510683

Gavrilović, Z., Maksimović, M. (2018). Green Innovations in the Tourism Sector, Strategic Management, 23(1), 36-42.

Hall C.M. (1999). Rethinking Collaboration and Partnership: A Public Policy Perspective, Journal of Sustainable Tourism, 7(3-4), 274-289, DOI: 10.1080/09669589908667340

Ingram, H. (1996). Classification and grading of smaller hotels, guesthouses and bed and breakfast accommodation, International Journal of Contemporary Hospitality Management, 8(5), pp. 30-34.

Marković, S., Ostojić, M., Popović, I. (2008). Rural tourism of SFRJ Yugoslavia has its origins in the vilages of Ivanjica, TO Ivanjica Reterived July 10, 2019, from https:// www.ivatourism.org/images/DOKUMENTA/Kongres_Osjek_\%202012.pdf

Marković, S., Ostojić, M., Popović, I. (2011). Golija - the potential leader in eco tourism in the Balkans, VII Naučno stručni skup sa međunarodnim učešćem, Kvalitet 2011, (01-04 juni) Neum, Bosna i Hercegovina. 
Milovanović, A., Milovanovic, B. (2010). Representation of the Climate Characteristics of Golija in Function of Space Evaluation, Proceedings - Faculty of Geography, University of Belgrade, 58, 29-46.

Miljanović, D. (2005). State of the Environment in the Area of Nature Park Golija, Bulletin of the Serbian Geographical Society, 85 (1), 249-264.

Lakićević, M., \& Durkalić, D. (2018). Measurement of tourism market performance in EU countries: results of PROMETHEE - GAIA approach, III International Scientific Conference "Tourism in function of development of Republic of Serbia - Tourism in the Era of Digital Transformation”, (pp.443-451), Vrnjačka Banja.

Lakićević, M., \& Žarevac Bošković M. (2018). The role of modern event - based tourism industry in the tourism development in the Republic of Serbia, I International Scientific Conference "Tourism in Function of Development of Republic of Serbia - Spa Tourism in Serbia and Experiences of Other Countries", (pp.99-116), Vrnjačka Banja.

Leech, N., Barrett, K., Morgan, G. (2005). SPSS for Intermediate Statistics: Use and Interpretation. Second Edition. New Jersey: Lawrence Erlbaum Associates, Publishers.

Long, P., Lane, B. (2000) Rural tourism development in: Gartner, W. C.; Lime, D. W. Trends in outdoor recreation, leisure and tourism. CABI Publishing 2000, pp.299-308, DOI : 10.1079/9780851994031.0299

Ostojić, M., Marković, S., Popović, I. (2008). Influence of development of touristic arrangements on improving life quality of people in Ivanjica area, Festival kvaliteta, 13-15 maj Kragujevac, (pp.61-67), Reterived July 15, 2019 from http://www.cqm.rs/2008/pdf/3/05.pdf

Ostojić, M., Marković, S., Popović, I. (2010). Assessment of tourism quality in the Morava area based on swot analzsis, Reterived July 15, 2019 from https:/www. ivatourism.org/images/DOKUMENTA/Festival\%20kvaliteta_KG_2010.pdf

Sharpley, R. (2002). Rural tourism and the challenge of tourism diversification: the case of Cyprus, Tourism Management, 23 (3), 233-244, DOI: 10.1016/S0261-5177(01)00078-4

Sheskin, D. (2004). Handbook of Parametric and Nonparametric Statistical Procedures, $3^{\text {rd }}$ edition. United States of America: Library of Congres.

Šušić, V., Đorđević, D. (2019). Modern Tendencies of Internacional Tourism Development, Ekonomika, 65(2), 27-37. doi:10.5937/ekonomika1902027S

Ritchie, J. B., Crouch, G. I. (2003). The Competitive Destination: A Sustainable Tourism Perspective. Oxon,CABI Publishing.

Official Gazette of the Municipality of Ivanjica, Reterived July 15, 2019 from https://www. paragraf.rs/opstinska-newsletters / ivanjica / ivanjica_pdf / ivanjica-05-2017.pdf

Vuković, P. (2018). The formation and promotion of rural tourist product in the Republic of Serbia, Ekonomika, 64(4), 82-91 doi:10.5937/ekonomika1804079V

Žarevac, M., Lakićević, M., Vujović, V. (2013). Strategic foundations of the cultural tourism development in Vrnjci Spa, Anali Ekonomskog fakulteta u Subotici, 49(30), 195-206.

Internet references:

Website Tourism Organization Ivanjica www.ivatourism.org (15.07.2019).

http://www.turistickiklub.com/objekat/golija (15.07.2019). 